\title{
ANALISIS WACANA LISAN \\ PADA MAHASISWA ANTARDAERAH DI YOGYAKARTA
}

\author{
Syukriati \\ J1. Pendidikan no 35 Dasan Agung Baru, Kota Mataram, Indonesia \\ UIN Mataram \\ Pos-el: dewi.abidjar@gmail.com
}

\begin{abstract}
This study aims to to study and analyze oral discourse in student funds reside in yogyakarta. Oral discourse that occur in the form of the use of intervening code ( code-switching ) by college students coming from java and outside java.Methods used is the method is to take a. the use of language. The subject of the research is a student who comes from several areas live in one. for lodging A technique used in the data collection techniques basic listening and engineering advanced slc (simak libat cakap) because researchers to participate or were directly involved in conversation and give the conversation. The result showed that the context of the talks is different from other regions of the students were could lead to the code in the intervening daily communication. With a code adopted code from intervening in the form of words and phrases.
\end{abstract}

Keywords: discourses, oral discourse, code mixing

\begin{abstract}
Abstrak
Penelitian ini bertujuan untuk mengkaji dan menganalisis wacana lisan pada mahasiswa antardaerah yang berdomisili di Yogyakarta. Wacana lisan yang terjadi adalah dalam bentuk penggunaan campur kode (code-switching) oleh mahasiswa yang berasal dari pulau Jawa dan luar pulau Jawa. Metode yang digunakan adalah metode simak yaitu dengan menyimak penggunaan bahasa. Subjek dalam penelitian ini adalah beberapa mahasiswa yang berasal dari beberapa daerah yang tinggal dalam satu pemondokan (kost). Teknik yang digunakan dalam pengumpulan data yaitu teknik dasar sadap dan teknik lanjutan SLC (Simak Libat Cakap) karena peneliti ikut berpartisipasi dan terlibat langsung dalam percakapan sambil menyimak percakapan tersebut. Hasil penelitian menunjukkan bahwa konteks terjadinya pembicaraan yaitu perbedaan asal daerah dari para mahasiswa tersebut dapat menimbulkan terjadinya fenomena campur kode dalam komunikasi sehari-hari. Campur kode yang digunakan berwujud campur kode yang berbentuk kata dan frase atau klausa. Jenis campur kode yang digunakan adalah campur kode kedalam (inner code-mixing). Penggunaan campur kode bertujuan untuk mengubah suasana menjadi santai, menyesuaikan topik pembicaraan serta untuk
\end{abstract} (14-27) 
mendapatkan ketepatan makna dalam berkomunikasi. Faktor penyebab terjadinya campur kode dalam penelitian tersebut adalah karena penutur dan lawan tutur (petutur) dari subjek penelitian berasal dari latar belakang bahasa daerah yang berbeda.

Kata Kunci: analisis wacana, wacana lisan, campur kode

\section{PENDAHULUAN}

Bahasa merupakan sarana komunikasi sosial yang utama dalam kehidupan manusia (language is a means). Oleh karena itu, kedudukannya dalam masyarakat sangatlah penting karena bahasa memiliki peran fundamental yang tidak mungkin dilepaskan untuk mewujudkan interaksi sosial antara individu baik secara perorangan maupun kelompok. Kenyataan ini menunjukkan bahwa bahasa menentukan terwujudnya kegiatan interaksi sosial antar anggota masyarakat atau dengan kata lain suatu masyarakat tidak akan bersosialisasi tanpa bahasa.

Dilihat dari sudut pandang sosiolinguistik, sebagai salah satu cabang ilmu linguistik yang mempelajari aspek kemasyarakatan dalam bahasa, masyarakat sosial merupakan kesatuan. Belajar bahasa atau mengamati gejala perubahan bahasa perlu memperhatikan konteks sosial tempat bahasa itu tumbuh dan berkembang. Konteks sosial yang berbeda-beda tentu akan memunculkan variasi bahasa yang berbeda pula. Adanya berbagai macam variasi bahasa tersebut menjadi pilihan bagi pemakai bahasa sesuai dengan keperluannya. Para pemakai bahasa secara sadar atau tidak sadar dapat mengubah gaya bahasanya sesuai dengan situasi yang dihadapinya. Hal ini dapat menyebabkan bahasa sebagai alat komunikasi memiliki banyak variasi sesuai dengan konteksnya. Variasi bahasa tersebut akan terus bertambah seiring dengan kepentingan dan peranan pemakai bahasanya.

Pada masyarakat Indonesia yang terdiri dari bermacam-macam budaya, ras dan etnik dengan sendirinya terdapat pula berbagai macam variasi bahasa yang digunakan untuk berkomunikasi antar anggota masyarakatnya. Berkaitan dengan hal ini, masyarakat Indonesia merupakan masyarakat multibahasa yang sarat dengan permasalahan bahasa. Pemakaian bahasa dalam masyarakat yang dwibahasa atau multibahasa merupakan gejala yang menarik untuk dikaji.

Keanekaragaman yang ada dalam masyarakat Indonesia salah

Sukriati, Analisis Wacana Lisan ........ (14-27) 
satunya juga dapat terlihat di suatu kota atau daerah yang menjadi tempat tujuan belajar atau menuntut ilmu oleh para pelajar dan mahasiswa. Di Indonesia terdapat banyak kota yang dijadikan sebagai tujuan untuk menuntut ilmu, salah satunya adalah kota Yogyakarta yang menjadi kota tujuan para pelajar dan mahasiswa dari seluruh Indonesia untuk bersekolah atau kuliah. Keanekaragaman asal daerah dari mahasiswa yang mendiami kota Yogyakarta tentunya akan dibarengi dengan keanekaragaman penggunaan bahasa oleh mereka dalam berkomunikasi sehari-hari. Hal ini disebabkan, seperti yang dijelaskan sebelumnya, bahwa masyarakat Indonesia adalah masyarakat multibahasa yang memiliki kemampuan menggunakan lebih dari satu bahasa untuk berkomunikasi.

Fenomena ini membuat penulis tertarik untuk melakukan penelitian sederhana dan menganalisis tentang penggunaan bahasa oleh mahasiswa antardaerah yang ada di Yogyakarta. Penggunaan bahasa yang dimaksud tentunya adalah bahasa lisan yang biasa mereka gunakan untuk berkomunikasi sehari-hari. Dalam penelitian sederhana ini, fenomena kebahasaan yang dikaji yaitu tentang penggunaan campur kode (codeswitching) oleh mahasiswa antardaerah ketika mereka berinteraksi. Campur kode yang dimaksud yaitu mencampur penggunaan bahasa Jawa dan bahasa Indonesia, karena subjek penelitian yang akan diteliti berasal dari pulau Jawa dan luar pulau Jawa. Penelitian ini akan dikaji dalam bentuk kajian wacana lisan dengan menggunakan pendekatan sosiolinguistik karena berhubungan dengan aspek kemasyarakatan dalam penggunaan bahasa tersebut.

Bahasa lisan atau wacana lisan pada dasarnya merupakan hal utama yang menjadi pokok bahasan dalam suatu kajian wacana, hal ini seperti yang ditulis oleh Mulyana (2010: 2) bahwa wacana yang sesungguhnya dalam kajian wacana adalah wacana lisan, yaitu tuturan yang langsung disampaikan secara verbal. Sementara, wacana tulis merupakan wacana turunan yang lebih mirip dengan "wacana dokumentasi". Melalui analisis terhadap wacana lisan, akan diperoleh berbagai aspek yang masih melingkupinya. Misalnya, siapa yang bertutur, di mana tuturan tersebut terjadi, dalam situasi apa tuturan itu berlangsung, kapan terjadinya, dan untuk tujuan apa wacana itu dituturkan, dan sebagainya.

Aspek-aspek yang melingkupi wacana lisan tersebut, banyak pula yang dikaji dan dianalisis dengan menggunakan pendekatan sosiolinguistik karena berkaitan dengan aspek sosial kemasyarakatan dari pembicara atau penuturnya. Oleh karena itu, dalam tulisan inipun wacana lisan yang diamati akan dikaji dengan pendekatan sosiolinguistik terutama yang berkaitan 
dengan fenomena penggunaan campur kode oleh mahasiswa antardaerah di Yogyakarta dalam berkomunikasi sehari-hari. Kartomiharjo dalam Sumarlam (2009: 156) mengatakan bahwa analisis wacana berupaya menganalisis suatu wacana untuk sampai pada suatu makna yang sama atau dekat dengan makna yang dimaksud oleh pembicara dalam wacana lisan atau penulis dalam wacana tulis. Untuk mencapai tujuan tersebut analisis wacana banyak menggunakan pula sosiolinguistik, suatu cabang ilmu bahasa yang menelaah penggunaan bahasa dalam masyarakat, perantiperantinya serta temuan-temuan yang penting.

Kridalaksana (2009: 259) mendefinisikan wacana (discourse) sebagai satuan bahasa ter-lengkap yang dalam hierarki grama-tikal merupakan satuan gramatikal tertinggi atau terbesar. Wacana ini kemudian direalisasikan dalam bentuk karangan yang utuh (novel, bu$\mathrm{ku}$, seri ensiklopedia, dsb), paragraf, kalimat, atau kata yang membawa amanat yang lengkap.

Definisi lain yang hampir sama diuraikan pula oleh Mulyana (2010: 1) bahwa wacana merupakan unsur kebahasaan yang relatif paling kompleks dan paling lengkap. Satuan pendukung kebahasaanya meliputi fonem, morfem, kata, frasa, klausa, kalimat, paragraf, hingga karangan yang utuh.

Kajian wacana berkaitan dengan pemahaman tentang tindakan manusia yang dilakukan dengan bahasa (verbal) dan bukan bahasa (nonverbal). Untuk memahami wacana dengan baik dan tepat diperlukan bekal 'pengetahuan kebahasaan' dan bukan hanya 'kebahasaan secara umum'.

Arifin (2006:3) menyatakan bahwa kajian atau analisis wacana adalah kajian yang meneliti atau menganalisis bahasa yang digunakan secara alamiah, baik dalam bentuk tulis maupun lisan. Penggunaan bahasa secara alamiah ini berarti penggunaan bahasa seperti dalam komunikasi sehari-hari dan lebih ditekankan pada kajian penggunaan bahasa dalam konteks sosial, khusunya interaksi antarpenutur.

Dalam penelitian sederhana ini, wacana yang dikaji adalah wacana lisan (berkaitan dengan campur kode) yang digunakan secara alamiah oleh para penutur mahasiswa antardaerah di Yogyakarta dalam komunikasi mereka sehari-hari. Penelitian dilakukan di sebuah pemondokan yang dihuni oleh mahasiswa yang berasal dari pulau Jawa dan luar pulau Jawa.

Mulyana (2010:7) menguraikan bahwa wacana memiliki dua unsur pendukung utama, yaitu unsur

Sukriati, Analisis Wacana Lisan ........ (14-27) 
dalam (internal) dan unsur luar (eksternal). Unsur internal berkaitan dengan aspek formal kebahasaan, sedangkan unsur eksternal berkenaan dengan hal-hal diluar wacana itu sendiri. Kedua unsur tersebut membentuk satu kepaduan dalam suatu struktur yang utuh dan lengkap.

a. Unsur Internal Wacana

Unsur internal suatu wacana terdiri atas satuan kata atau kalimat. Dalam hal ini satuan kata yang dimaksud adalah kata yang berposisi sebagai kalimat atau disebut 'kalimat satu kata'. Untuk menjadi satuan wacana yang besar, satuan kata atau kalimat tersebut akan bertalian dan bergabung membentuk wacana.

b. Unsur Eksternal Wacana

Unsur eksternal wacana adalah sesuatu yang menjadi bagian wacana, namun tidak nampak secara eksplisit. Sesuatu itu berada diluar satuan lingual wacana dan kehadirannya berfungsi sebagai pelengkap keutuhan wacana. Salah satu unsur eksternal dalam wacana adalah konteks wacana. Pemahaman suatu wacana juga sangat memerlukan pemahaman terhadap konteks terjadinya wacana tersebut.

Dalam penelitian ini, wacana lisan yang ditemukan akan dikaji dari kedua unsur wacana tersebut yaitu unsur internal yang berwujud kata, frase, klausa dan kalimat yang digunakan oleh para pembicara.
Kata, frase, klausa dan kalimat itu adalah dalam bentuk campur kode yang mereka gunakan ketika berkomunikasi. Unsur eksternal yang juga akan dibahas yaitu konteks terjadinya wacana lisan (pembicaraan), disamping itu akan diuraikan juga tentang hal-hal lain seperti jenis campur kode yang digunakan, serta tujuan dan faktor digunakannya campur kode dalam komunikasi mereka.

Wacana dapat diklasifikasikan dalam berbagai aspek dan sudut pandang, salah satunya yaitu dilihat dari media penyampaiannya. Berdasarkan media penyampaiannya, wacana dipilah menjadi dua, yaitu wacana tulis dan wacana lisan (Mulyana, 2010:51). Wacana tulis (written discourse) adalah jenis wacana yang disampaikan melalui tulisan. Arifin dan Rani (2006:3) menguraikan bahwa dalam wacana tulis, ide-ide atau gagasan disampaikan dalam bentuk kodekode kebahasaan yang bia-sanya berupa rangkaian kalimat-kalimat berwujud teks yang makna-nya ditafsirkan sendiri oleh pem-baca.

Wacana lisan (spoken discourse) adalah jenis wacana yang disampaikan secara lisan atau langsung dengan bahasa verbal. Jenis wacana ini sering disebut sebagai tuturan (speech) atau ujaran (utterance) (Mulyana, 2010:52). Dalam wacana lisan, komunikasi disampaikan dalam bentuk lisan berupa rangkaian ujaran. Dalam proses komunikasi ini, 
para peserta tutur secara bergantian berbicara dengan atau tanpa topik yang jelas. Ketika seseorang bertindak sebagai pembicara dapat menyampaikan informasi, mengajak, memerintah, menyampaikan, pendapat, dan sebagainya.

Sebaliknya, mitra tutur mendengarkan, kemudian bersiapsiap berganti peran sebagai pembicara untuk merespon pembicaraan terdahulu.

Wacana lisan sangat dipengaruhi oleh konteks dan bersifat temporer yang fana (artinya setelah diucapkan lang-sung hilang), sehingga penafsir-annya harus melibatkan konteks ketika ujaran tersebut diucapkan (Arifin dan Rani, 2006:4)

Wacana lisan memiliki beberapa kelebihan dibandingkan dengan wacan tulis, diantaranya: (i) bersifat alami (natural) dan langsung, (ii) mengandung unsur-unsur prosodi bahasa (lagu, intonasi), (iii) memiliki sifat suprasentensial (di atas struktur kalimat), dan (iv) berlatar belakang konteks situasi. Bila dicermati, kelebihan-kelebihab tersebut pada dasarnya merupakan sifat dari wacana lisan. Hal tersebut disebabkan karena di sekeliling wacana lisan, sudah tersedia sejumlah aspek nonlinguistik yang benarbenar tidak nampak secara eksplisit, tetapi ada dan sangat berpengaruh terhadap makna dan keutuhan wacana itu sendiri (Mulyana, 2010: 52).

Dalam penelitian ini, wacana lisan yang diamati adalah penggunaan campur kode oleh mahasiswa antardaerah dalam komunikasi lisan mereka sehari-hari. Pembicaraan berlangsung secara alami dengan berbagai topik pembicaraan yang berbeda-beda sesuai dengan kondisi yang terjadi saat itu.

Istilah campur kode merujuk pada pemakaian dua bahasa atau lebih dengan saling memasukkan unsur-unsur bahasa yang satu ke bahasa yang lain secara konsisten. Unsur-unsur tersebut dapat berupa kata, frasa, klausa atau kalimat.

Menurut Damayanti (2017) campur kode adalah penggunaan dua bahasa atau lebih atau ragam bahasa antara orang-orang yang sudah dikenal dengan akrab. Dalam situasi berbahasa yang informal ini, seseorang dapat dengan bebas mencampur kode satu bahasa atau ragam bahasa apabila terdapat istilah-istilah yang tidak dapat diungkapkan dengan bahasa lain. Dalam kenyataannya, penggunaan campur kode antara kedua bahasa yang berbeda dilakukan dengan sengaja tanpa mengubah topik yang sedang dibicarakan. Dengan penggunaan campur kode, seorang penutur menunjukkan kedekatan serta solidaritas terhadap lawan tuturnya. Di samping itu, kebiasaan $(14-27)$ 
melakukan campur kode terkadang menjadi alasan untuk memperlihatkan status sosial dan identitas pribadi dalam masyarakat. Hal tersebut sesuai dengan ciri yang dapat dilihat dari campur kode yaitu kesantaian atau situasi informal, sedangkan dalam situasi formal, penggunaan campur kode biasanya disebabkan karena tidak ada ungkapan yang tepat dalam bahasa yang sedang digunakan, sehingga perlu memakai kata atau ungkapan dari bahasa lain.

Campur kode dipakai oleh penutur memamerkan keterpelajarannya atau kedudukannya. Selain itu, campur kode dapat digunakan untuk mencapai ketepatan makna ungkapan (Rahadi, 2010).

Ada juga penutur yang melakukan campur kode ini untuk menegaskan atau menekankan, menunjukkan keterpelajaran, mengubah suasana menjadi santai atau melucu, menggaya untuk menyesuaikan dengan topik pembicaraan atau ketepatan makna, untuk memberikan pelajaran atau pendidikan kepada orang lain, untuk menghormati atau menyelaraskan tingkat tutur, dan sebagainya.

Berdasarkan unsur-unsur yang dicampur dalam peristiwa campur kode, maka dapat digolongkan menjadi dua, yaitu:

1. Campur kode kedalam (inner codemixing) yaitu campur kode yang bersumber dari bahasa asli dengan segala variasinya.
2. Campur kode kedalam (outer codemixing) yaitu campur kode yang berdasarkan dari bahasa asing.

Kunjana (2010) membedakan campur kode menjadi beberapa macam, antara lain berdasarkan bahasa dan ragam bahasa yang dipakai penutur dan tuturannya, wujud unsur kebahasaan yang terlibat dalam campur kode, dan arah tuturan dalam campur kode. Campur kode bahasa terjadi bila seorang penutur menyisipkan unsurunsur bahasa daerah atau bahasa asing kedalam tuturannya. Campur kode ragam bahasa terjadi bila seorang penutur mencampur ragam bahasa yang satu dan ragam bahasa yang lain dalam sebuah kalimat. Campur kode wujud kebahasaan adalah campur kode yang berdasar pada pemakaian bahasa unsur-unsur bahasa lain yang disisipkan oleh penutur dalam tuturannya. Campur kode wujud kebahasaan berupa kata atau frase. Campur kode dapat berjalan dari bahasa A ke bahasa B begitu pula sebaliknya. Keadaaan seperti itu dapat dipengaruhi oleh latar belakang penutur, makna tertentu dan sebagainya. Campur kode yang berdasarkan pada arah tuturan disebut dengan campur kode arah tuturan.

Campur kode terjadi karena ada timbal balik antara peranan atau siapa yang memakai bahasa itu dan fungsi kebahasaan atau apa yang ingin dicapai penutur dalam tuturannya. Artinya penutur yang 
mempunyai latar belakang sosial tertentu memilih bentuk campur kode tertentu untuk mendukung fungsi-fungsi tertentu (Giyoto, 2013). Dapat disimpulkan bahwa penyebab yang mendorong terja-dinya campur kode, antara lain: (a) penutur, (b) petutur, (c) topik pembicaraan.

Penutur yang multibahasa memiliki banyak kesempatan untuk melakukan campur kode. Kehetorogenan latar belakang petutur (lawan tutur) seperti usia, status sosial dan tingkat pendidikan menuntut kepandaian penutur dalam memilih bahasa yang tepat. Namun dalam hal ini yang paling penting adalah bahwa penutur harus mengetahui bahwa petuturnya juga merupakan multi bahasawan. Topik pembicaraan memungkinkan terjadinya campur kode karena beberapa topik cenderung menuntut pemakaian kode bahasa tersendiri.

\section{METODOLOGI PENELITIAN}

Campur kode adalah merupakan bagian dari variasi bahasa dalam sosiolinguistik. Penelitian dalam bidang sosiolinguistik salah satunya dapat dilakukan dengan menggunakan metode linguistik seperti yang diuraikan oleh Sudaryanto(2015). Metode yang digunakan dalam penelitian ini adalah metode simak atau penyimakan. Menurut Sudaryanto (2015:2) metode ini disebut dengan metode simak atau penyimakan karena memang berupa penyimakan atau dilakukan dengan menyimak yaitu menyimak penggunaan bahasa. Metode ini dapat disejajarkan dengan metode pengamatan atau observasi dalam ilmu sosial, khususnya antropologi.

Subjek dalam penelitian ini adalah semua penghuni pemondokan (kost) di tempat kost peneliti yang terdiri dari lima orang termasuk peneliti sendiri. Subjek penelitian berasal dari Jawa tengah-Tegal, Cilacap, Purworejo dan Demak-dan Bima-NTB. Mereka semua dilibatkan sebagai subjek penelitian karena peneliti hampir sepanjang hari selalu berinteraksi dengan mereka tanpa terkecuali. Komunikasi yang terjadi hampir selalu mempergunakan campur kode bahasa Jawa dan bahasa Indonesia, sehingga menurut peneliti semua penghuni kost tersebut sangat tepat dan cukup efektif dijadikan sebagai subjek penelitian untuk mendapatkan data yang dibutuhkan.

Setting Penelitian semua cuplikan percakapan yang dijadikan data penelitian diambil di tempat kost peneliti yaitu di Jalan Gejayan Gang Kwera no. 8, SlemanYogyakarta. Waktu pengambilan data selama tiga hari yaitu pada tanggal 10, 12 dan 13 Januari 2017. Waktu pengambilan data dipilih $(14-27)$ 
pada saat subjek penelitian sedang berkumpul atau sedang melakukan aktivitas bersama-sama seperti menonton televisi, memasak atau sekedar berkumpul untuk saling bertukar cerita.

Dalam penelitian ini, peneliti memulai pengumpulan data dengan teknik dasar sadap karena untuk mendapatkan data, peneliti terlebih dahulu harus menyadap pembicaraan subjek penelitian. Kemudian teknik lanjutan SLC dipergunakan karena peneliti ikut berpartisipasi dan terlibat langsung dalam percakapan sambil menyimak percakapan tersebut. Hal tersebut menyebabkan subjek penelitian tidak menyadari bahwa mereka sedang dijadikan subjek dalam penelitian. Teknik lanjutan lain yang dipakai adalah teknik rekam dan teknik catat, karena pada saat melakukan penyimakan peneliti juga mempergunakan alat perekam serta melakukan pencatatan secara sederhana untuk menjaga agar data yang ingin dikumpulkan tidak hilang dan terlupakan begitu saja. Hal ini tentunya dilakukan secara diamdiam tanpa sepengatahuan subjek penelitian sehingga tidak mengganggu kewajaran proses percakapan yang terjadi.

Data yang ditemukan dalam penelitian ini, kemudian dianalisis dengan langkah-langkah sebagai berikut: (1) mendeskripsikan konteks terjadinya wacana lisan (pembicaraan) yang dilakukan oleh subjek penelitian, (2) data campur kode yang diperoleh dalam penelitian, yang berupa rekaman dan catatan dari cuplikan percakapan diuraikan dalam bentuk tulisan, (3) data tersebut kemudian dipotong dan diidentifikasikan berdasarkan wujud campur kode yang dibutuhkan, (4) mendeskripsikan jenis campur kode yang digunakan dan menguraikan tujuan serta faktor penyebab penggunaan campur kode tersebut berdasarkan penelitian yang dilakukan, dan (5) menyimpulkan hasil analisis data.

\section{HASIL DAN PEMBAHASAN}

\section{a. Konteks Terjadinya Wacana Lisan (Pembicaraan)}

Dari penelitian ini, ditemukan bahwa terjadinya penggunaan campur kode oleh subjek penelitian adalah ditentukan oleh konteks terjadinya wacana lisan (pembicaraan) tersebut. Konteks yang dimaksud yaitu, perbedaan latar belakang bahasa daerah dari subjek penelitian itu sendiri. Mereka berasal dari daerah yang berbeda, yaitu dari pulau Jawa dan luar pulau Jawa sehingga secara otomatis mereka juga memiliki bahasa daerah yang berbeda. Hal tersebut mengharuskan mereka untuk selalu mencampur penggunaan bahasa Jawa dan bahasa Indonesia ketika berkomunikasi untuk mempermudah proses komunikasi dan pemahaman mereka dalam berinteraksi. Uraian lebih mendalam tentang 
penggunaan campur kode ini dapat ditemukan juga dalam pembahasanpembahasan berikutnya yang menguraikan tentang jenis campur kode, tujuan dan faktor penggunaan campur kode berdasarkan teori-teori yang telah diuraikan sebelumnya. Berbagai pembahasan tersebut tentunya masih berkaitan dengan konteks terjadinya wacana lisan dalam penelitian ini.

\section{b. Wujud Campur Kode dalam Wacana Lisan yang Ditemukan}

Berdasarkan data yang diperoleh dari beberapa cuplikan percakapan yang dilakukan oleh subjek penelitian, peneliti menemukan bahwa wujud campur kode yang mereka gunakan sebagaian besar adalah berbentuk kata dan frase atau klausa. Campur kode yang berwujud kalimat lengkap dan panjang sangat jarang ditemukan. Pada dasarnya ketika mereka berkomunikasi dengan sesama penghuni yang berasal dari Jawa mereka akan menggunakan bahasa Jawa lengkap meskipun terkadang tetap menyisipkan bahasa Indonesia, akan tetapi ketika mereka berkomunikasi dan berinteraksi dengan peneliti sendiri, mereka sangat jarang menggunakan bahasa Jawa yang lengkap dan panjang untuk menghindari miskomunikasi karena mereka menyadari bahwa peneliti berasal dari luar Jawa.
Namun, sebaliknya mereka juga jarang berkomunikasi dengan peneliti dengan menggunakan bahasa Indonesia yang lengkap karena mereka mengetahui bahwa peneliti telah beberapa tahun menetap di Jawa sehingga sedikitbanyak akan memahami bahasa Jawa yang mereka sisipkan dalam percakapan sehari-hari. Bahasa Jawa yang mereka gunakan untuk berkomunikasi dengan peneliti pun dalam bentuk bahasa Jawa sederhana (Bahasa Jawa Ngoko) yang mereka perkirakan masih bisa dipahami dan dimengerti oleh peneliti. Bahasa Jawa yang digunakan oleh mereka juga terdapat beberapa kata yang masih dipengaruhi oleh dialek Banyumas karena dua orang subjek penelitian berasal dari Tegal dan Cilacap yang notabene selalu menggunakan dialek Banyumas tersebut dalam keseharian mereka di lingkungan keluarga.

\section{i. Campur kode yang berwujud kata}

a. Campur kode berwujud kata yang ditemukan dalam cuplikan percakapan 1:

"Mbak Dew, kowe ndue bukunya Moleong ora? Nggon aku dipijam si Astri..."

"Ehm..koyok ngene yo Mbak, S loro...!Bukunya aku silih dulu ya, tidak dipakai kan Mbak?" $(14-27)$ 
“Udu' Mbak, aku sesok arep konsultasi karo bu Prof. Aku wedi Mbak, piye iki..?"

"Iya opo Mbak? Mbak $\underline{\text { mbiyen }}$ kayak gini juga ya?"

"Ya sudah Mbak, doakan aku ya..nuwun Mbak!"

b. Campur kode berwujud kata yang ditemukan dalam cuplikan percakapan 2:

"Iya Mbak, jorok sekali padahal cowokke makannya biasa wae."

c. Campur kode berwujud kata yang ditemukan dalam cuplikan percakapan 3:

"Mbak Dew, hari ini kuliah jam piro?"

"Oh, ngono to? Yo wis lah, aku masak karo Mbak Nita wae."

ii. Campur kode yang berwujud frase atau klausa.

a. Campur kode berwujud frase atau klausa yang ditemukan dalam cuplikan percakapan 1:

"Mbak Dew, kowe ndue bukunya Moleong ora? Nggon aku dipijam si Astri."

"Ehm..koyok ngene ya Mbak, S loro...!Bukunya aku silih dulu ya, tidak dipakai kan Mbak?

"Udu' Mbak, aku sesok arep konsultasi karo bu Prof. Aku wedi Mbak, piye iki?" $(14-27)$ b. Campur kode berwujud frase atau klausa yang ditemukan dalam cuplikan percakapan 2:

"Masa' makan Soto diuwek-uwek koyok ngono."

"Iyah sih Mbak, tapi lek maem nang warung yo ojo koyok ngono, mesake liane sing maem."

"Lucu wae liate Mbak, ono yo cah wadon kayak gitu."

c. Campur kode berwujud frase atau klausa yang ditemukan dalam cuplikan percakapan 3:

"Ooo, kowe arep masak ora?"

"Tidak usah Mbak, kalau Mbak Dewi tidak masak. Aku tumbas nang Ibu bakulan wae, wis lewat urung ya?"

"Iyo yo, Mbar....kowe arep tumbas sayur ora? Engko lek Ibu bakulan lewat aku dipanggil ya. Aku ngresiki kamar se'."

"Belum tahu nih, lihat nanti.. memangnya kuliah jam piro to Mbak, biasanya dino Sebtu juga masak sama kita."

"Oh, ngono to? Yo wis lah, aku masak karo Mbak Nita wae.

\section{c. Jenis Campur Kode yang Digunakan oleh Subjek Penelitian}

Jenis campur kode yang digunakan oleh subjek penelitian dalam penelitian sederhana ini adalah campur kode kedalam (inner code-mixing) yaitu campur kode yang 
bersumber dari bahasa asli dengan segala variasinya. Dimana dalam penelitian ini, jenis campur kode kedalam dapat peneliti simpulkan sebagai campur kode yang digunakan pada suatu daerah yang masih berasal dari satu negara yang memiliki berbagai variasi bahasa daerah yang berbeda-beda tetapi tetap merujuk bahasa Indonesia sebagai bahasa asli dan bahasa nasional. Campur kode yang terjadi dalam penelitian ini sama sekali tidak ada atau tidak tercampur dan dipengaruhi oleh unsur bahasa asing. Bahasa asing disini peneliti artikan sebagai bahasa diluar atau selain dari bahasa yang berasal dari variasi bahasa daerah di Indonesia

\subsection{Tujuan Penggunaan Campur Kode oleh Subjek Penelitian}

Pada kajian teori yang telah dikemukakan di atas, campur kode dipakai oleh penutur dengan tujuan untuk menegaskan atau menekankan, menunjukkan keterpelajaran, mengubah suasana menjadi santai atau melucu, menggaya untuk menyesuaikan dengan topik pembicaraan atau ketepatan makna, untuk memberikan pelajaran atau pendidikan kepada orang lain, untuk menghormati atau menyelaraskan tingkat tutur, dan sebagainya.

Dalam penelitian ini, penggunaan campur kode bertujuan untuk memperlancar proses komunikasi, mengubah suasana menjadi santai, menyesuaikan topik pembicaraan serta untuk mendapatkan ketepatan makna dalam berkomunikasi dengan seseorang yang berasal dari luar daerah, yang dalam hal ini adalah peneliti sendiri sebagai salah satu dari subjek penelitian yang berasal dari luar daerah Jawa yaitu Bima, Nusa Tenggara Barat.

\subsection{Faktor yang Menyebabkan Terjadinya Campur Kode oleh Subjek Penelitian}

Penyebab yang mendorong terjadinya campur kode, antara lain: (a) penutur, (b) petutur, (c) topik pembicaraan. Penutur yang multibahasa memiliki banyak kesempatan untuk melakukan campur kode. Kehetoregenan latar belakang petutur (lawan tutur) seperti usia, status sosial dan tingkat pendidikan menuntut kepandaian penutur dalam memilih bahasa yang tepat. Namun dalam hal ini yang paling penting adalah bahwa penutur harus mengetahui bahwa petuturnya juga merupakan multibahasawan. Topik pembicaraan memungkinkan terjadinya campur kode karena beberapa topik cenderung menuntut pemakaian kode bahasa tersendiri.

Dalam penelitian ini, faktor penyebab terjadinya campur kode adalah karena penutur dan lawan tutur (petutur) dari subjek penelitian, yang dalam hal ini juga

Sukriati, Analisis Wacana Lisan ........ (14-27) 
termasuk peneliti sendiri, adalah berasal dari latar belakang bahasa daerah yang berbeda. Penutur dan petutur yang dijadikan sebagai subjek penelitian ini merupakan dwibahasawan dan bahkan multibahasawan di mana mereka dapat menguasai lebih dari satu bahasa dan dapat mempergunakannya dengan baik.

\section{SIMPULAN}

Banyak hal yang bisa dikaji melalui kajian wacana. Salah satunya yaitu mengkaji tentang penggunaan bahasa lisan oleh masyarakat Indonesia yang secara umum bersifat multibahasawan. Berbagai fenomena kebahasaan bisa muncul dari ke-multibahasawan-an tersebut, di antaranya adalah fenomena penggunaan campur kode dalam komunikasi sehari-hari. Dengan menggunakan pendekatan sosiolinguistik dan metode-metode linguistik, penggunaan wacana lisan campur kode tersebut dapat dikaji dan dianalisis. Penelitian sederhana pada mahasiswa antardaerah yang telah dilakukan diatas, ditemukan bahwa konteks terjadinya pembicaraan yaitu perbedaan asal daerah dari para mahasiswa tersebut dapat menimbulkan terjadinya fenomena campur kode dalam komunikasi mereka sehari-hari, hal tersebut dilakukan untuk mempermudah proses komunikasi dan pemahaman mereka ketika berinteraksi. Campur kode yang terjadi adalah dengan $(14-27)$ mencampur bahasa Jawa dan bahasa Indonesia, karena mereka berasal dari pulau Jawa dan luar pulau Jawa.

Dalam penelitian sederhana tersebut, campur kode yang digunakan berwujud campur kode yang berbentuk kata dan frase atau klausa. Jenis campur kode yang digunakan adalah campur kode kedalam (inner code-mixing) yaitu campur kode yang bersumber dari bahasa asli dengan segala variasinya dan dalam penelitian ini, campur kode yang terjadi sama sekali tidak ada atau tidak tercampur dan dipengaruhi oleh unsur bahasa asing. Penggunaan campur kode bertujuan untuk mengubah suasana menjadi santai, menyesuaikan topik pembicaraan serta untuk mendapatkan ketepatan makna dalam berkomunikasi dengan seseorang yang berasal dari daerah yang berbeda. Faktor penyebab terjadinya campur kode dalam penelitian tersebut adalah karena penutur dan lawan tutur (petutur) dari subjek penelitian berasal dari latar belakang bahasa daerah yang berbeda.

\section{DAFTAR PUSTAKA}

Arifin, Bustanul \& Abdul Rani. (2006). Prinsip-prinsip Analisis Wacana. Jakarta: Direktorat Jenderal Pendidikan Tinggi, DP4M. 
Damayanti, Rini dan Savitri

Suryandari. (2017).

Psikolinguistik. Surabaya :

Kresna Bina Insan Mandiri

Giyoto. (2013). Pengantar

Sosiolinguistik. Surakarta :

Fataba.

Kridalaksana, Harimurti. (2009). Kamus linguistik. Edisi keempat. Jakarta: Gramedia Pustaka Utama

Mulyana. (2010). Kajian Wacana: Teori, Metode E Aplikasi PrinsipPrin-sip Analisis Wacana. Yogyakarta: Tiara Wacana.

Rahadi, Kunjana. (2010). Kajian Sosiolinguistik. Yogyakarta : Ghalia Indonesia.

Sudaryanto. (2015). Metode Linguistik. Yogyakarta: Gajah Mada University Press.

Sumarlam. (2009). Teori dan Praktik Analisis Wacana. Surakarta: Pustaka Cakra 